\title{
Entamoeba histolytica-secreted cysteine proteases induce IL-8 production in human mast cells via a PAR2-independent mechanism
}

\author{
Young Ah Lee ${ }^{1}$, Young Hee Nam ${ }^{1}$, Arim Min ${ }^{1}$, Kyeong Ah Kim ${ }^{1}$, Tomoyoshi Nozaki ${ }^{2}$, \\ Yumiko Saito-Nakano ${ }^{2}$, David Mirelman ${ }^{3}$, and Myeong Heon Shin ${ }^{1, *}$ \\ ${ }^{1}$ Department of Environmental Medical Biology, Institute of Tropical Medicine, and Brain Korea 21 Project for Medical Science, \\ Yonsei University College of Medicine, Seoul 120-752, Korea \\ 2 Department of Parasitology, National Institute of Infectious Diseases, 1-23-1 Toyama, Shinjuku-ku, Tokyo, Japan \\ 3 Department of Biological Chemistry, Weizmann Institute of Science, Rehovot 76100, Israel
}

Received 30 June 2013, Accepted 23 January 2014, Published online 7 February 2014

\begin{abstract}
Entamoeba histolytica is an extracellular tissue parasite causing colitis and occasional liver abscess in humans. E. histolytica-derived secretory products (SPs) contain large amounts of cysteine proteases (CPs), one of the important amoebic virulence factors. Although tissue-residing mast cells play an important role in the mucosal inflammatory response to this pathogen, it is not known whether the SPs induce mast cell activation. In this study, when human mast cells (HMC-1 cells) were stimulated with SPs collected from pathogenic wild-type amoebae, interleukin IL-8 mRNA expression and production were significantly increased compared with cells incubated with medium alone. Inhibition of CP activity in the SPs with heat or the CP inhibitor E64 resulted in significant reduction of IL-8 production. Moreover, SPs obtained from inhibitors of cysteine protease (ICP)-overexpressing amoebae with low CP activity showed weaker stimulatory effects on IL-8 production than the wild-type control. Preincubation of HMC-1 cells with antibodies to human protease-activated receptor 2 (PAR2) did not affect the SP-induced IL- 8 production. These results suggest that cysteine proteases in E. histolytica-derived secretory products stimulate mast cells to produce IL-8 via a PAR2-independent mechanism, which contributes to IL-8-mediated tissue inflammatory responses during the early phase of human amoebiasis.
\end{abstract}

Key words: Entamoeba histolytica, Cysteine protease, Mast cell, IL-8, Protease-activated receptor 2 (PAR2).

\begin{abstract}
Résumé - Les cystéine protéases secrétées par Entamoeba histolytica induisent la production d'IL-8 chez les mastocytes humains par un mécanisme indépendant de PAR2. Entamoeba histolytica est un parasite extracellulaire des tissus provoquant des colites et occasionnellement des abcès du foie chez l'homme. Les produits de sécrétion dérivés d'E. histolytica (SPs) contiennent de grandes quantités de cystéine-protéases (CPs), l'un des principaux facteurs de virulence amibiens. Bien que les mastocytes tissulaires jouent un rôle important dans la réponse inflammatoire de la muqueuse à ce pathogène, on ne sait pas si les SPs induisent l'activation des mastocytes. Dans cette étude, lorsque des mastocytes humains (cellules HMC-1) ont été stimulés avec des SPs recueillis à partir d'amibes pathogènes de type sauvage, l'expression et la production de l'interleukine IL-8 ont été significativement augmentées par rapport à des cellules incubées avec du milieu seul. L'inhibition de l'activité des CPs dans les SPs avec la chaleur ou avec E64, un inhibiteur de CP, a entraîné une réduction significative de la production d'IL-8. En outre, les SPs obtenus à partir d'amibes surexprimant l'inhibiteur de protéases à cystéine (ICP) à faible activité de $\mathrm{CP}$ ont montré des effets stimulants plus faibles sur la production d'IL-8 que le contrôle de type sauvage. La pré-incubation des cellules HMC-1 avec des anticorps contre le récepteur 2 activé par la protéase humaine (PAR2) n'a pas affecté la production d'IL-8 induite par SPs. Ces résultats suggèrent que les cystéine-protéases des produits de sécrétion dérivés d' $E$. histolytica stimulent les mastocytes pour produire de l'IL-8 par l'intermédiaire d'un mécanisme indépendant de PAR2, ce qui contribue à la réponse inflammatoire tissulaire médiée par IL-8 au cours de la phase précoce de l'amibiase humaine.
\end{abstract}

\footnotetext{
*Corresponding author: myeong@yuhs.ac
} 


\section{Introduction}

The enteric protozoan parasite Entamoeba histolytica Schaudinn, 1903 [25] is the causative agent of human amoebiasis. E. histolytica trophozoites bind colonic mucin via amoebic Gal-lectin and subsequently cause mucin degradation and colonic epithelial cell death through apoptosis or necrosis [19, 20]. $E$. histolytica releases various proteases into the extracellular milieu. In particular, cysteine proteases (CPs) are abundant in E. histolytica-derived secretory products (SPs). CPs are important for host mucin and extracellular matrix (ECM) degradation [11], cytopathic effects on the host cell, and activation of IL-1 $\beta$ or IL-18.

E. histolytica-induced colon cell death promotes IL-8-mediated acute tissue inflammation at the site of infection [26]. IL-8 is a potent chemoattractant and activator of neutrophils and can cause non-specific tissue damage after activation [9]. Although neutrophils are the primary target cells of IL- 8 , IL- 8 has other effects on various kinds of cells such as endothelial cells, other granulocytes, macrophages, and mast cells. The infiltration of immune cells including neutrophils, macrophages, and mast cells at the mucosal surface was observed during $E$. histolytica intestinal amoebiasis, suggesting that these cells might be important in host defense against this parasite [13]. Moreover, an increase in degranulation and disruption of mast cells was reported in E. histolytica-infected mice [16], suggesting that mast cells play a role in E. histolytica-induced tissue inflammation at the inflamed site. However, the precise role of amoebic CPs in mast cell activation is poorly understood.

Mast cells contribute to the innate and adaptive host defense mechanisms through the release of an arsenal of inflammatory mediators upon activation by various stimuli [3, 12]. Tissueresiding mast cells are major players in the mucosal inflammatory response to various bacterial and parasitic infections [6]. Activated mast cells release various proinflammatory mediators including histamine, IL-6, IL-8, IL-13, prostaglandin D2, leukotriene C4 (LTC4), and tumor necrosis factor- $\alpha$ (TNF- $\alpha$ ) in response to various stimuli [14]. The essential role of mast cells in the host control of infection has been shown in animal models infected with various bacterial and parasitic pathogens [2, 4, 28]. However, little is known about the effect of amoebic SPs on IL-8 secretion in mast cells.

In this study, mast cells were stimulated with E. histolyticaderived SPs from E. histolytica wild-type or mutant strains to ascertain if SPs directly induce IL- 8 production. The results of this work show that amoebic CPs participate in SP-induced IL-8 production in HMC-1 cells.

\section{Materials and methods}

\section{Reagents}

Unless stated otherwise, all other chemicals were purchased from Sigma-Aldrich (Saint Louis, MO, USA). Mouse monoclonal antibody $(\mathrm{Ab})$ against human protease-activated receptor
2 (PAR2) (SAM 11) and normal mouse $\operatorname{IgG}_{2 \mathrm{a}}$ were purchased from Santa Cruz Biotechnology (Santa Cruz, CA, USA). Fluorescent isothiocyanate (FITC)-labeled annexin V, PEconjugated anti-human CD63, and PE-conjugated anti-mouse $\mathrm{IgG}_{1} \kappa$ were purchased from BD Pharmingen (San Diego, CA, USA). Dichlorodihydrofluorescein diacetate ( $\mathrm{H}_{2}$ DCFDA) was purchased from Molecular Probes (Eugene, OR, USA).

\section{Cultivation of human HMC-1 cells}

The HMC-1 human mast cell line was grown in Iscove's Modified Dulbecco's medium (IMDM) (Invitrogen) containing $10 \%(\mathrm{v} / \mathrm{v})$ heat-inactivated fetal bovine serum (FBS) and $0.5 \%$ penicillin-streptomycin at $37{ }^{\circ} \mathrm{C}$ in a humidified $5 \% \mathrm{CO}_{2}$ atmosphere. HMC-1 cell viability, as judged by trypan blue exclusion testing, was $99 \%$.

\section{Culture of bone marrow-derived murine mast cells (BMMCs) and ethics}

BMMCs from BALB/c mice (Orient Bio, Seoul, Korea) were obtained by culturing mouse femoral bone marrow cells in RPMI containing $10 \%(\mathrm{v} / \mathrm{v})$ heat-inactivated fetal bovine serum, $\quad 0.5 \%$ penicillin-streptomycin, $50 \mu \mathrm{M} \quad \beta$-mercaptoethanol, and $20 \mathrm{ng} / \mathrm{mL}$ IL-3 (PeproTech, Rocky Hill, NJ, USA) for 4 weeks. At that time, the cells were $>98 \%$ c-kit $^{\text {high }}$ FceRI ${ }^{\text {high }}$, according to flow cytometric analysis using PE antimouse FceRIa (MAR-1) (eBioscience, San Diego, CA, USA) and FITC anti-mouse c-kit/CD117 (2D8) (eBioscience, San Diego, CA, USA). The present study was approved by the Yonsei University Animal Research Ethics Committee (No. 2013-0297).

\section{Construction of $E$. histolytica cell lines overexpressing a GFP-tagged inhibitor of cysteine protease $1\left(\mathrm{ICP}^{+/+}\right)$}

To create the ICP1-overexpressing E. histolytica cell line $\left(\mathrm{ICP} 1^{+/+}\right)$, a full-length $E$. histolytica ICP 1 gene was amplified by PCR from cDNA using sense and antisense oligonucleotides containing appropriate restriction sites (underlined) at the $5^{\prime}$ end: icpl $5^{\prime}$-aatcccgggATGTCATTAACTGAAGATAATAAC AACACAAC-3' (SmaI); and 5'-gggctcgagTTACTG GACAT TAACTTTTAAAGTAAAAG-3' (XhoI). The PCR-amplified DNA fragments were digested and ligated into the same restriction sites of the overexpression vector, pKT-MG. This vector allows for the expression of a gene of interest as a N-terminal fusion with GFP. The plasmids were introduced into $E$. histolytica HM-1:IMSS trophozoites by liposome-mediated transfection as previously described [22], and stable transformants were cultured in medium containing $8 \mu \mathrm{g} / \mathrm{mL}$ G418 (for $\mathrm{ICP}^{+/+}$and $\mathrm{pKT}-\mathrm{MG}$ as a vector control). 


\section{Cultivation of E. histolytica trophozoites and preparation of secretory products}

Trophozoites of the E. histolytica virulent HM-1:IMSS strain, the avirulent E. histolytica Rahman strain, and the hypo-CP strain ICP $1^{+/+}$were grown at $37{ }^{\circ} \mathrm{C}$ in TYI-S-33 medium as described previously [10]. After cultivation for 48-72 h, logarithmic growth phase trophozoites were harvested by incubation on ice for $10 \mathrm{~min}$, followed by centrifugation at $1000 \mathrm{rpm}$ at $4{ }^{\circ} \mathrm{C}$ for $5 \mathrm{~min}$. To collect SPs, trophozoites from the various strains were incubated in Hanks' balanced salt solution (GIBCO Laboratories, Grand Island, NY, USA) for $2 \mathrm{~h}$ at $37^{\circ} \mathrm{C}$ at a final concentration of $1 \times 10^{7}$ amoebae per $\mathrm{mL}$. The viability of Entamoeba trophozoites after incubation in Hank's balanced salt solution was $99 \%$ as determined by the trypan blue exclusion assay. Protein concentration was measured by the BCA protein assay using bovine serum albumin as a standard.

\section{Measurement of cell viability and cell death}

HMC-1 cell viability and cell death were measured by trypan blue and annexin V/propidium iodide (PI) double staining, respectively. HMC-1 cells $\left(5 \times 10^{5}\right.$ cells/sample) stimulated with SPs were incubated for $2 \mathrm{~h}$ at $37{ }^{\circ} \mathrm{C}$ in a humidified $\mathrm{CO}_{2}$ incubator $\left(5 \% \mathrm{CO}_{2}\right.$ and $95 \%$ air $)$. After incubation, the reaction was stopped by brief centrifugation, and the cells were washed with cold PBS twice and stained with FITC-conjugated annex in $\mathrm{V}$ and $1 \mu \mathrm{g} / \mathrm{mL}$ PI. Flow cytometric analysis was performed with a FACScan on at least 10,000 cells from the host cell fraction.

\section{Measurement of exocytosis in HMC-1 cells or BMMCs}

To elucidate the exocytosis of HMC-1 cells or BMMCs induced by the SPs, HMC- 1 cells or BMMCs $\left(5 \times 10^{5}\right.$ cells/ sample) were incubated with SP (30 or $100 \mu \mathrm{g} / \mathrm{mL}$ ) for $2 \mathrm{~h}$, or platelet-activating factor (PAF) $(5 \mu \mathrm{M})$ for $1 \mathrm{~h}$ or phorbol 12-myristate 13-acetate (PMA) for $2 \mathrm{~h}$. For positive control, BMMCs were treated with monoclonal anti-DNP IgE $(250 \mathrm{ng} / \mathrm{mL})$ for $4 \mathrm{~h}$, and then the cells were challenged with DNP-HSA $(250 \mathrm{ng} / \mathrm{mL})$ for $1 \mathrm{~h}$ to trigger mast cell degranulation. After incubation, the cells were washed twice with washing buffer $(0.1 \%$ sodium azide and $1 \%$ FBS in PBS) and stained with PE-conjugated anti-human or anti-mouse CD63. PE-conjugated anti-mouse $\operatorname{IgG}_{1}$ or anti-rat $\operatorname{IgG}_{2 \mathrm{a}}$ was used as an isotype control. A flow cytometric analysis was performed using a FACScan on at least 10,000 cells from each sample.

\section{Quantitative real-time PCR for IL-8 mRNA expression}

HMC-1 cells $\left(1 \times 10^{6} /\right.$ sample $)$ were incubated with or without SPs for 30 min at $37{ }^{\circ} \mathrm{C}$ in a $\mathrm{CO}_{2}$ incubator. After incubation, total RNA was obtained from HMC-1 cells $\left(1 \times 10^{6} \%\right.$ sample) incubated with or without SPs using TRIzol reagent (Invitrogen Corporation, Carlsbad, CA, USA) and was reverse-transcribed using a ProSTAR first-strand RT-PCR kit (Stratagene, La Jolla, CA, USA). Obtained cDNA was amplified using a SYBR ${ }^{\circledR}$ Green PCR Master Mix. The primers used were as follows: human IL-8; 5'-TCT GCA GCT CTG TGT GAA GGT G-3' and 5'-AAT TTC TGT GTT GGC GCA GTG-3', human GAPDH; 5'-GAA GGT GAA GGT CGG AGT $\mathrm{C}-3^{\prime}$ and 5'-GAA GAT GGT GAT GGG ATT TC-3'. IL-8 gene expression was analyzed using the Applied Biosystems 7700 Sequence Detection System (Applied Biosystems, Foster City, CA, USA), according to the manufacturer's instructions. The relative amount of mRNA for the genes of interest was determined by subtracting the threshold cycle $(\mathrm{Ct})$ values for the gene from the $\mathrm{Ct}$ value for the internal control gene Glyceraldehyde-3-phosphate dehydrogenase (GAPDH) $(\Delta \mathrm{Ct})$. Each measurement of a sample was performed in triplicate. The data represent IL-8 mRNA fold induction.

\section{IL-8 ELISA}

For measurement of IL-8 production, HMC- 1 cells $\left(5 \times 10^{5} \%\right.$ well) were seeded in 24-well tissue culture plates and then directly incubated for the indicated times with or without native or modified SPs for $12 \mathrm{~h}$ at $37^{\circ} \mathrm{C}$ in a $\mathrm{CO}_{2}$ incubator. After incubation, culture supernatants were collected from HMC-1 cells. To evaluate the involvement of PAR2 in SP-induced IL-8 production, HMC- 1 cells $\left(5 \times 10^{5} /\right.$ well $)$ were preincubated with anti-PAR2 $(10 \mu \mathrm{g} / \mathrm{mL})$ or mouse $\operatorname{IgG}_{2 \mathrm{a}}(10 \mu \mathrm{g} / \mathrm{mL})$ for $30 \mathrm{~min}$. After preincubation, the cells were incubated for the indicated times with or without native SPs for $12 \mathrm{~h}$ at $37{ }^{\circ} \mathrm{C}$ in a $\mathrm{CO}_{2}$ incubator. Then, culture supernatants were collected from HMC- 1 cells, and the amount of IL- 8 production was measured with a specific human IL-8 screening kit (Thermo Scientific, Waltham, MA, USA) according to the manufacturer's instructions.

\section{Measurement of cysteine protease activity}

Native SPs obtained from wild-type amoebae were pretreated with or without protease inhibitor (E64 or PMSF) or heat-modified SPs $\left(100^{\circ} \mathrm{C}\right.$ for $\left.10 \mathrm{~min}\right)$, and then $\mathrm{CP}$ assays were performed. In addition, $\mathrm{ICP}^{+++}$, vector control, or Rahman-derived native SPs were also measured for CP activity. Briefly, E. histolytica trophozoites $\left(4 \times 10^{5} /\right.$ well) were incubated in $100 \mathrm{~mL}$ Opti-MEM medium (Invitrogen, Carlsbad, CA, USA) supplemented with $137 \mathrm{mM}$ cysteine and $19 \mathrm{mM}$ ascorbic acid, $\mathrm{pH} 6.8$ in a 96-well tissue culture plate at $37^{\circ} \mathrm{C}$ for $1 \mathrm{~h}$. After incubation, the culture supernatant for secreted CP activity was collected and remaining trophozoites for intracellular CP activity were obtained by centrifugation. $\mathrm{CP}$ activity was measured according to the cleavage of a z-Arg-Arg-pNA2 $\mathrm{HCl}$ synthetic peptide substrate, which was monitored spectrophotometrically as described previously [21, 23]. 

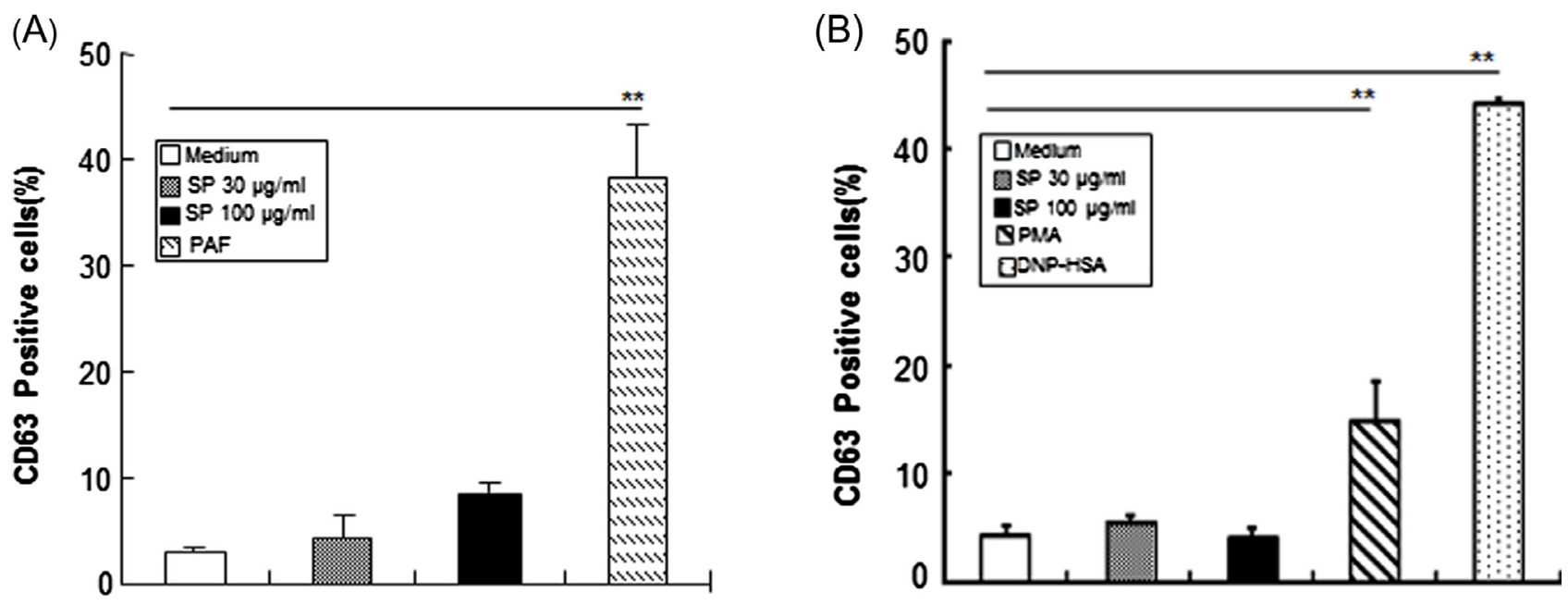

(C)

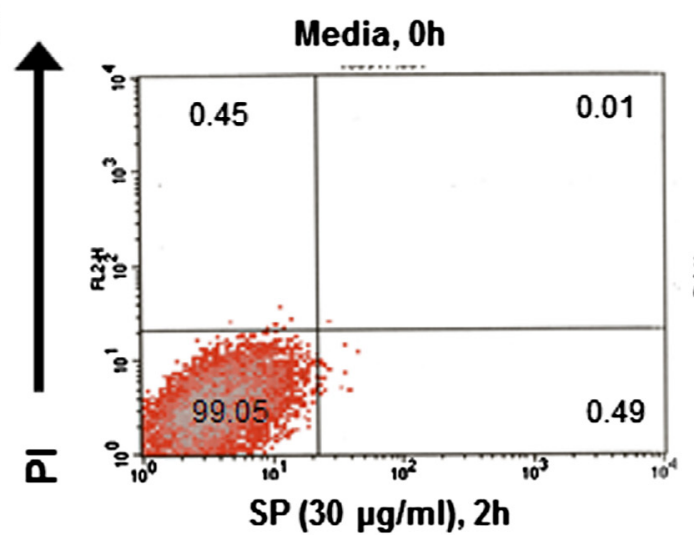

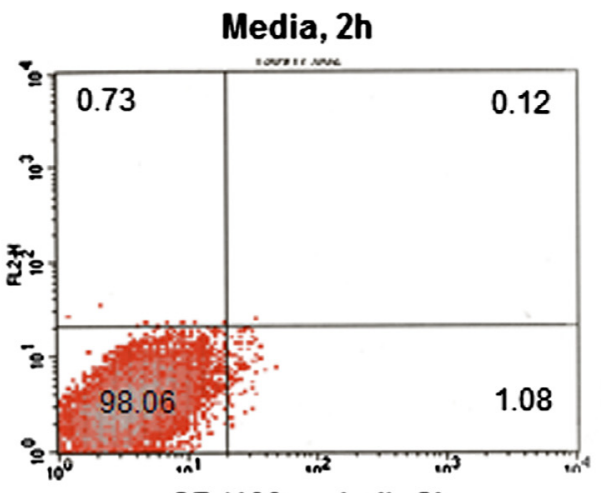

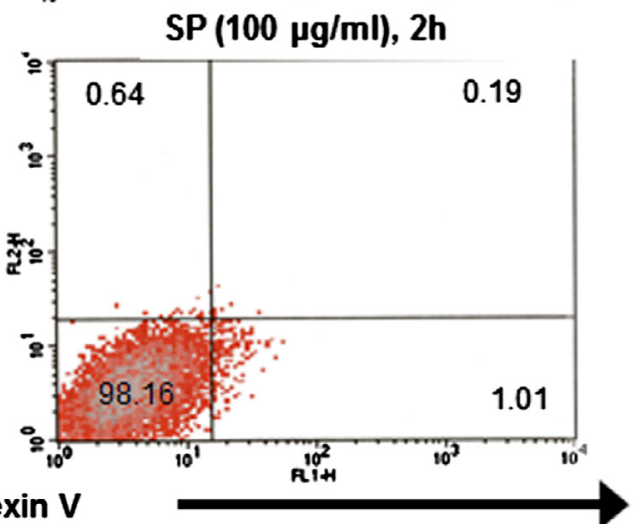

Figure 1. E. histolytica-derived secretory products (SPs) of pathogenic amoebae do not induce cell death or exocytosis in mast cells. (A) Percentage of CD63-positive cells in HMC-1 cells incubated with SPs or platelet-activating factor (PAF) $(5 \mu \mathrm{M})$. ( $n=3)$ (B) Percentage of CD63-positive cells in bone marrow-derived murine mast cells incubated with SPs, phorbol 12-myristate 13-acetate (PMA) (50nM) or DNPHSA $(250 \mathrm{ng} / \mathrm{mL})$. $(n=4)$. (C) Flow cytometry analysis of HMC-1 cell death after stimulation with or without SPs. $(n=4)$. All reactions were performed in triplicate measurements of each experiment. All data are presented as the mean \pm SEM of at least three independent experiments. The asterisks indicate the results of comparisons with the controls $(* * p<0.01)$.

\section{Measurement of ROS generation in HMC-1 cells}

Intracellular ROS accumulation in HMC-1 cells was measured by staining cells with the green fluorescence probe $\mathrm{H}_{2}$ DCFDA, which is rapidly oxidized to highly fluorescent DCF in the presence of intracellular $\mathrm{H}_{2} \mathrm{O}_{2}$, and analyzed spec- trofluorometrically (model Axiovert 200). Briefly, HMC-1 cells $\left(1 \times 10^{5}\right.$ cells/sample) were preloaded with $5 \mu \mathrm{M} \mathrm{H} \mathrm{H}_{2}$ DCFDA for $30 \mathrm{~min}$ and washed twice with culture medium. The washed cells were incubated with or without SPs or PAF for up to $30 \mathrm{~min}$ at $37{ }^{\circ} \mathrm{C}$ in a $\mathrm{CO}_{2}$ incubator. The production of intracellular ROS was determined on a Perkin Elmer LS50B 
(A)

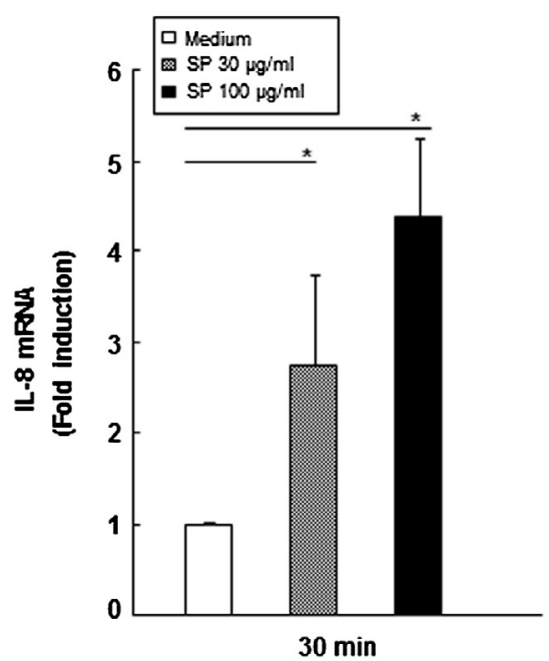

(B)

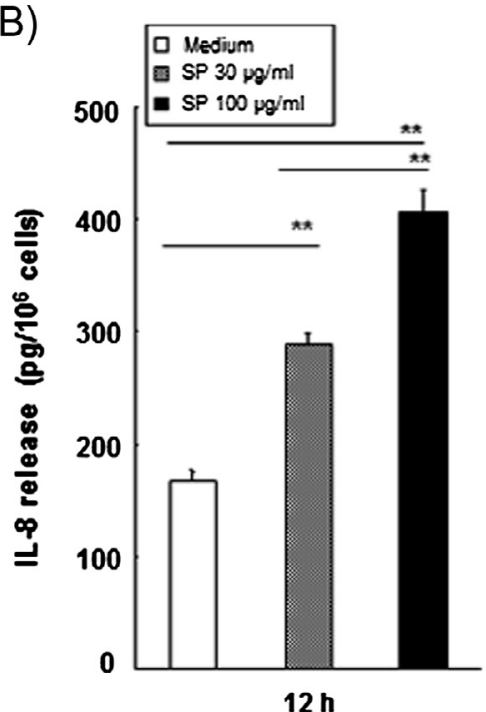

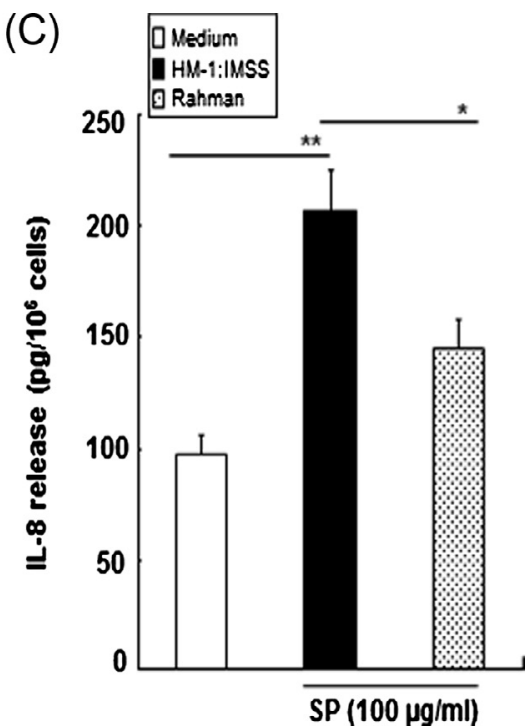

Figure 2. E. histolytica-derived secretory products (SPs) from the pathogenic wild-type HM-1:IMSS strain induce IL-8 gene expression and protein secretion in HMC-1 cells. (A) Increased $I L-8$ mRNA expression in HMC-1 cells induced by SPs. $(n=3)(B)$ IL- 8 production in SPsstimulated HMC-1 cells. $(n=6)(\mathrm{C})$ Comparison of IL-8 production in HMC-1 cells stimulated with SPs obtained from wild-type or nonpathogenic Rahman strains. $(n=4)$. All reactions were performed in triplicate measurements of each experiment. Data are presented as the mean \pm SEM of at least three independent experiments. The asterisks indicate the results of comparisons with the controls $\left({ }^{*} p<0.05\right.$, $* * p<0.01)$.

spectrofluorometer using excitation and emission wavelengths of 485 and $530 \mathrm{~nm}$, respectively. All background fluorescence was subtracted using the appropriate controls.

\section{Statistical analysis}

All reactions were performed in triplicate measurements of each experiment. Results are presented as the mean \pm SEM of 3 to 6 independent experiments. One-way analysis of variance (ANOVA) was performed using the statistical software package SPSS version 20 for Windows. The post hoc comparisons of means from different groups were made by the Bonferroni post hoc test. Values were considered statistically significant when the $p$-value $\leq 0.05$.

\section{Results}

\section{E. histolytica-derived secretory products do not induce mast cell degranulation}

HMC-1 cells were treated with various concentrations (30 or $100 \mu \mathrm{g} / \mathrm{mL}$ ) of SPs for $2 \mathrm{~h}$ to examine whether SPs could induce mast cell activation. CD63 expression is generally used as a surface marker for degranulation via exocytosis in mast cells [24]. When HMC-1 cells or BMMCs were treated with $100 \mu \mathrm{g} / \mathrm{mL} \mathrm{SP}$ for $2 \mathrm{~h}$, the percentage of CD63-positive cells was $8.1 \pm 1.7$ and $4.0 \pm 0.6$, respectively. However, HMC-1 cells treated with $5 \mu \mathrm{M}$ PAF or BMMCs treated with DNPHSA as a positive control showed a marked increase in CD63 expression (Figure 1A and 1B). At that time, there was no difference in cell viability after incubation with SPs for
$2 \mathrm{~h}$ compared with the results for HMC-1 cells (Figure 1C) or BMMCs (data not shown) incubated with medium alone.

\section{Stimulation with secretory products increased IL-8 mRNA expression and protein secretion in HMC-1 cells}

To examine whether SPs could induce secretion of IL-8 in HMC-1 cells, real-time PCR and ELISA analyses were performed. The real-time PCR analysis revealed that HMC-1 cells stimulated with SPs for $30 \mathrm{~min}$ resulted in a 3- to 4-fold increase in IL- 8 mRNA as compared with cells treated with medium alone (Figure 2A). As shown in Figure 2B, SPstimulated HMC-1 cells released IL-8 protein in a dose-dependent manner, and HMC-1 cells stimulated with SPs for $12 \mathrm{~h}$ resulted in a 1.7- and 2.4-fold increase in IL-8 protein at 30 and $100 \mu \mathrm{g} / \mathrm{mL} \mathrm{SP}$, respectively, compared with medium-treated cells. There was no difference in the number of annexin Vpositive HMC-1 cells after incubation with SPs for $12 \mathrm{~h} \mathrm{com-}$ pared with the results for cells incubated with medium alone (data not shown). Interestingly, SPs from the non-pathogenic Rahman strain showed a 30\% reduction compared with SPs from HM-1:IMSS amoebae (Figure 2C).

\section{Cysteine protease activity is required for IL-8 production in HMC-1 cells induced by secretory products}

To determine if amoebic CPs obtained from wild-type HM-1:IMSS SPs are responsible for SP-triggered IL-8 


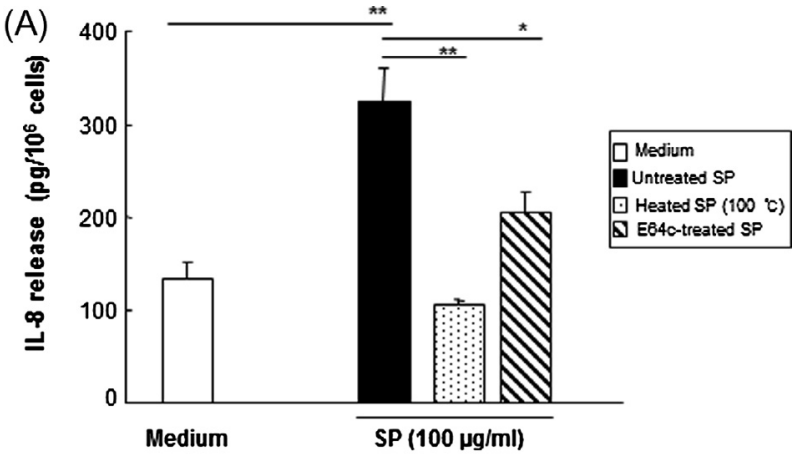

(B)

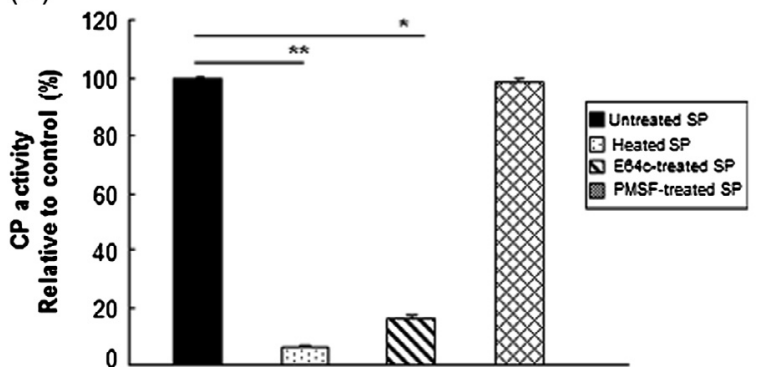

Figure 3. Amoebic cysteine protease activity is required for IL-8 production in HMC-1 cells induced by $E$. histolytica-derived secretory products (SPs). (A) IL-8 production in HMC-1 cells stimulated with SPs from native or modified wild-type SPs either heat-treated $\left(100{ }^{\circ} \mathrm{C}, 10 \mathrm{~min}\right)$ or treated with $25 \mu \mathrm{M}$ protease inhibitor $(\mathrm{E} 64 \mathrm{c}) .(n=4)(\mathrm{B}) \mathrm{CP}$ activity from native or modified wild-type SPs with heat- $\left(100{ }^{\circ} \mathrm{C}, 10 \mathrm{~min}\right)$ or $25 \mu \mathrm{M}$ protease inhibitor (E64c or PMSF) treatment were measured using z-ArgArg-pNA.2 $\mathrm{HCl}$ as a substrate. The level of activity is shown as a percentage relative to the control. $(n=3)$. All reactions were performed in triplicate measurements of each experiment. Data are presented as the mean \pm SEM of at least three independent experiments. The asterisks indicate the results of comparisons with the controls $\left({ }^{*} p<0.05 .{ }^{* *} p<0.01\right)$.

production in mast cells, modified SPs were incubated with HMC-1 cells. As shown in Figure 3A, the IL-8 production induced by SPs was abolished by pretreatment of the SPs with heat, suggesting that Entamoeba-secreted heat-labile protein components may participate in IL-8 production in HMC-1 cells. SP-induced IL-8 production in HMC-1 cells was significantly reduced by pretreatment of the SPs with the cysteine protease inhibitor E64c. Next, we compared the CP activity of native or modified SPs by treatment with specific protease inhibitors. As shown in Figure 3B, cysteine protease inhibitor E64c-treated SPs and heat-treated SPs from the wild-type significantly reduced CP activity as compared with untreated SPs. In contrast, serine protease inhibitor PMSF-treated SPs had no inhibitory effect on CP activity. To demonstrate that amoebic CP is responsible for SP-triggered IL-8 production in mast cells, we observed the IL- 8 production in HMC-1 cells by SPs from the $\mathrm{ICP} 1^{+/+}$strain. SPs derived from the ICP $1^{+/+}$strain resulted in a decrease in IL-8 production compared with its transfectant control (Figure 4A). In addition, a marked reduction of CP activity was observed in SPs obtained from the $\mathrm{ICP}^{+/+}$strain compared with its vector control amoebae (Figure 4B).
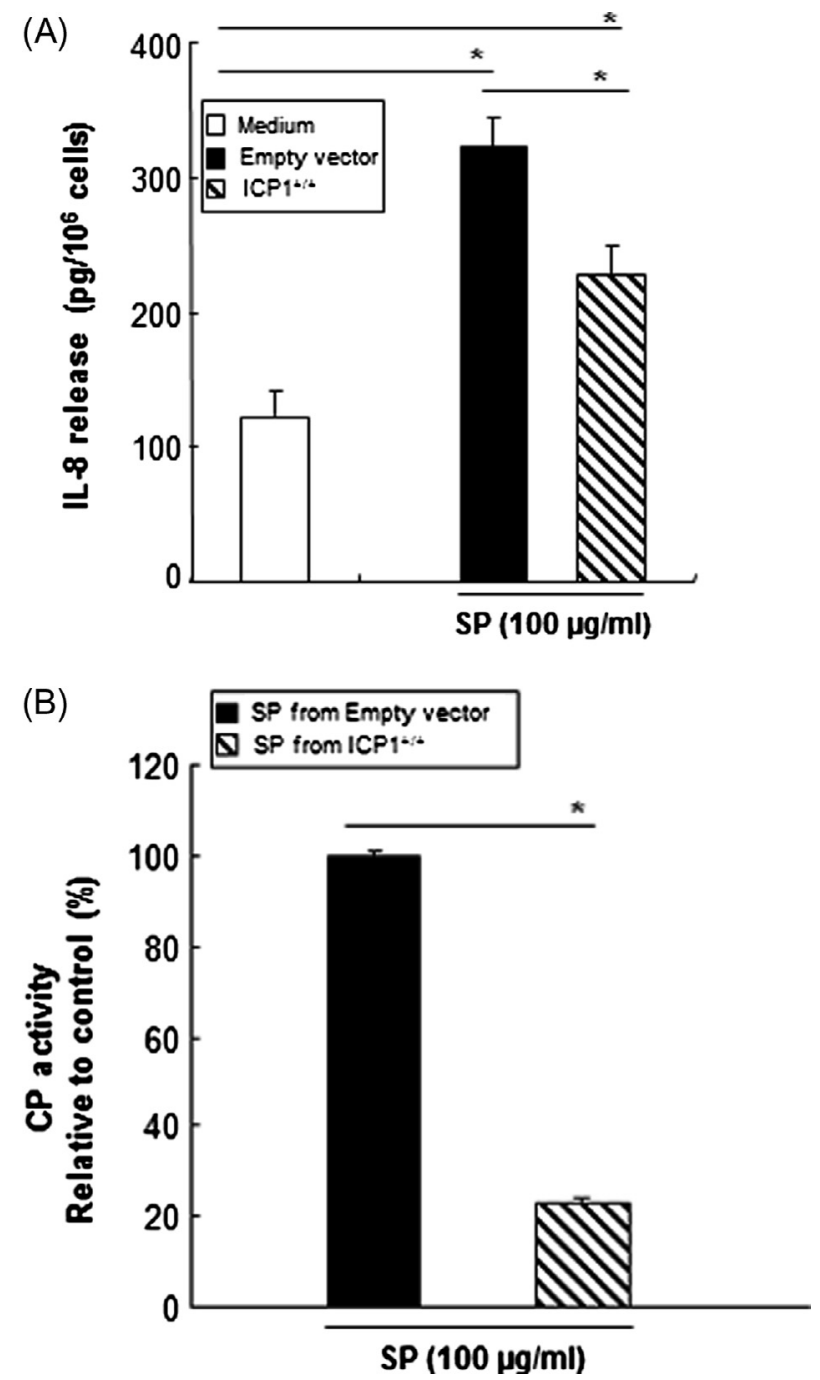

Figure 4. E. histolytica-derived secretory products (SPs) from the inhibitor of cysteine protease $1\left(\mathrm{ICP}^{+/+}\right)$strain show a reduction in IL-8 protein secretion and cysteine protease activity in HMC-1 cells. (A) IL-8 production in HMC-1 cells stimulated with SPs from the $\mathrm{ICP} 1^{+/+}$or vector control strain. $(n=4)(\mathrm{B})$ The CP activity of SPs from the ICP $1^{+/+}$or vector control strain was measured using $\mathrm{z}$-ArgArg-pNA. $2 \mathrm{HCl}$ as a substrate. $(n=3)$. All reactions were performed in triplicate measurements of each experiment. Data are presented as the mean \pm SEM of at least three independent experiments. The asterisks indicate the results of comparisons with the controls $\left({ }^{*} p<0.05\right)$

\section{Secretory products-induced IL-8 production in HMC-1 cells occurs through a PAR2- and ROS-independent mechanism}

Next, we investigated whether PAR2, which is a known G-coupled receptor, is involved in IL-8 production induced by SPs. HMC-1 cells were preincubated with monoclonal $\mathrm{Ab}$ $(10 \mu \mathrm{g} / \mathrm{mL})$ to PAR2 or the isotype control $\mathrm{IgG}_{2 \mathrm{a}}$ for $30 \mathrm{~min}$ at room temperature and subsequently incubated for $12 \mathrm{~h}$ with or without SPs. As shown in Figure 5A, Ab to PAR2 did not 
(A)

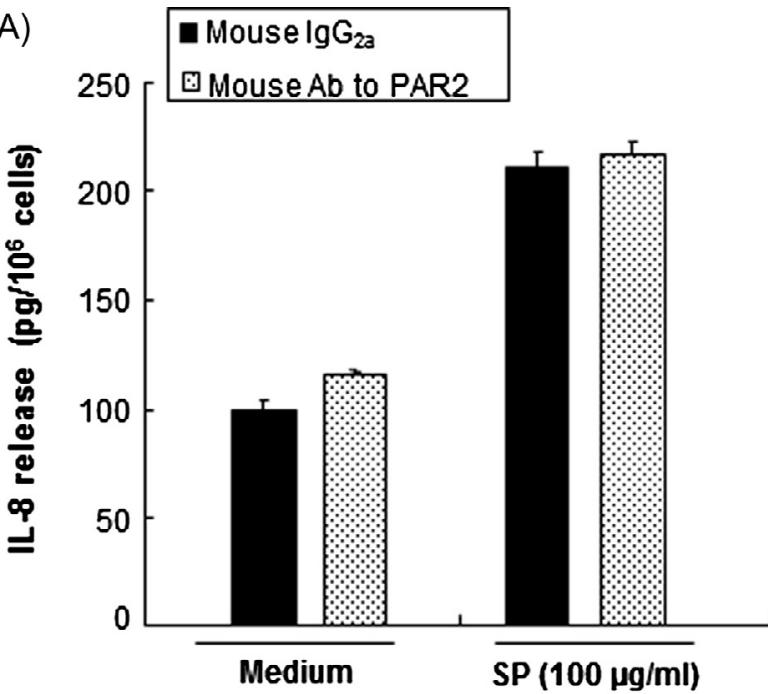

(B)

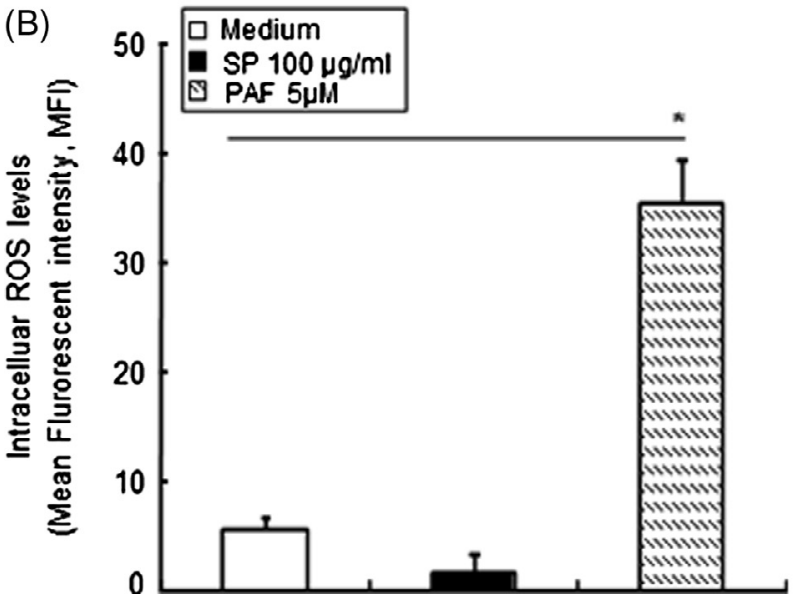

Figure 5. E. histolytica-derived secretory product (SP)-induced IL-8 production in HMC-1 cells occurs through a protease-activated receptor 2 (PAR2) or ROS-independent mechanism. (A) The effect of anti-PAR2 on SP-stimulated IL-8 production. $(n=4)$ (B) The effect of SPs on induction of ROS generation at $30 \mathrm{~min}$ in HMC-1 cells. $(n=3)$. All reactions were performed in triplicate measurements of each experiment. Data are presented as the mean \pm SEM of at least three independent experiments. The asterisks indicate the result of comparisons with the control $\left({ }^{*} p<0.05\right)$.

inhibit SP-induced IL-8 production in HMC-1 cells. Next, we investigated whether ROS were involved in the SP-induced IL-8 production in HMC-1 cells. As shown in Figure 5B, intracellular ROS were not detected in SP-stimulated HMC-1 cells within $30 \mathrm{~min}$. In contrast, intracellular ROS levels were strongly increased in HMC-1 cells stimulated with PAF as a positive control.

\section{Discussion}

In this study, our results show that amoebic CP participates in IL-8 production through a PAR2-independent pathway in HMC-1 cells. E. histolytica-derived SPs containing serine or amoebic CPs have been shown to constantly secrete CPs into the extracellular environment $[1,18]$. The SPs of the Rahman and $\mathrm{ICP}^{+/+}$strains resulted in a significant decrease in IL-8 production in HMC-1 cells compared with the SPs of wild-type Entamoeba, suggesting that a reduction in $\mathrm{CP}$ activity may result in a significant reduction of SP-induced IL-8 production in HMC-1 cells. Our data indicate that amoebic CP might be involved in IL-8 production in HMC-1 cells.

Recent work has shown that E. histolytica SPs can markedly increase IL-8 mRNA expression and protein production in colonic epithelial cells [9]. In addition, recent studies have provided evidence that chemokines such as IL- 8 are crucial mediators in inflammation and in tissue injury in intestinal inflammation. IL-8 is a small, 8 - to $11-\mathrm{kDa}$ secreted protein that may participate in immune and inflammatory responses through chemoattraction and activation of neutrophils or leukocytes [1]. $E$. histolytica invades the intestinal mucosa and causes amoebic colitis and severe ulceration. Analysis of the inflammatory response during intestinal amoebiasis in human and animal models of the disease has revealed an important regulatory role for chemokines and cytokines. Recruitment and activation of inflammatory cells are modulated by secreted amoebic factors. SPs contain many components including cysteine protease (CP), serine protease, other proteases, phosphatases and prostaglandin E2 (PGE2).

In our preliminary experiment, we got IL-8 results of HMC-1 cells stimulated with five various concentrations ( 0 , $10,30,100$, and $200 \mu \mathrm{g} / \mathrm{mL}$ ) of SP. However, no effect of $10 \mu \mathrm{g} / \mathrm{mL}$ of SP on IL-8 production was observed. In addition, the highest concentration of SP $(200 \mu \mathrm{g} / \mathrm{mL})$ showed a cytotoxic effect on HMC-1 cells (about 10\% of cells were dead for $12 \mathrm{~h}$ ), although the amount of IL-8 release in SP $(200 \mu \mathrm{g} / \mathrm{mL})$-stimulated cells showed a similar level compared with the result of stimulation with $100 \mu \mathrm{g} / \mathrm{mL}$ (data not shown). As a result, we chose 30 and $100 \mu \mathrm{g} / \mathrm{mL}$ concentrations for all experiments.

In the present study, the amount of IL- 8 production in HMC- 1 cells induced by heat-treated SPs $\left(100^{\circ} \mathrm{C}\right.$ for $\left.10 \mathrm{~min}\right)$ abrogated IL-8 production, suggesting that heat-labile proteins participate in IL-8 production in HMC-1 cells. Interestingly, this result is consistent with the fact that the RGD motif in promature CP5 (PCP) binds to integrin of colon cells and induces NF-kB-mediated IL-8 production in Caco-2 cells [15]. In addition, SPs from the Rahman strain resulted in a significant decrease in IL-8 production in HMC-1 cells, whereas IL-8 production by the $\mathrm{ICP}^{+/+}$strain, which is deficient in CP, was slightly diminished. This result is in agreement with the report that the Rahman strain decreased CP expression. According to a previous report [9], PGE2 participation in SP-induced IL-8 production was demonstrated in colon cells, where boiled amoebic secretory product $\left(100{ }^{\circ} \mathrm{C}\right.$ for $\left.30 \mathrm{~min}\right)$ abolished SP-stimulated IL-8 production. However, involvement of the lipid mediator PGE2 in SP-stimulated IL-8 production in HMC-1 cells was not investigated in this study.

There is no information on how SPs can induce mast cell activation such as IL-8 release. G-coupled receptors or Toll-like receptors (TLR) residing on the mast cell surface may act as the biological sensor for various infectious agents during the process of mast cell activation. For example, certain proteases, including serine protease and trypsin, are signaling molecules 
that regulate cells by cleaving and triggering PARs [27]. Accordingly, involvement of the PAR2 receptor that is activated by serine protease and occasionally by cysteine protease was tested. In particular, PAR2 is closely related to inflammation [8]. Although SPs contain many kinds of proteases including serine, cysteine and aspartic proteases, SP-induced IL-8 production in mast cells did not occur via the PAR2 receptor. Also, it is well known that TLRs act as biological sensors of various infectious agents (i.e., viruses, bacteria, or fungi) or their products (such as lipopolysaccharide, lipoteichoic acid, and peptidoglycan) and are expressed by various innate immune cells (i.e., macrophages, neutrophils, or dendritic cells) $[7,17]$. In addition to recognizing external dangers, TLRs also regulate the immune response by recognizing endogenously produced danger signals including necrotic cells, heat shock proteins, or ECM breakdown products [5]. As such, TLRs may participate in SP-induced mast cell activation; however, more experimentation is needed to investigate TLR involvement in response to SPs.

In conclusion, we have demonstrated that CPs present in SPs contribute to IL-8 production in human mast cells. Additionally, non-pathogenic Rahman and the CP-deficient $\mathrm{ICP}^{+/+}$strains showed a decrease in IL-8 production, suggesting the involvement of amoebic CP in the host cell response induced by E. histolytica infection, helping us to understand the mechanism of pathogenesis in E. histolytica.

Acknowledgements. We would like to thank Myung-hee Yi for her help with purification of BMMCs. This study was supported by a National Research Foundation of Korea (NRF) grant funded by the Korean Government (MEST) (number 2009-0070766).

\section{References}

1. Ajuebor MN, Swain MG. 2002. Role of chemokines and chemokine receptors in the gastrointestinal tract. Immunology, 105, 137-143.

2. Askenase PW. 1977. Immune inflammatory responses to parasites: the role of basophils, mast cells and vasoactive amines. American Journal of Tropical Medicine and Hygiene, 26, 96-103.

3. Beaven MA. 2009. Our perception of the mast cell from Paul Ehrlich to now. European Journal of Immunology, 39, 11-25.

4. Befus AD, Bienenstock J. 1982. Immunity to infectious agents in the gastrointestinal tract. Journal of the American Veterinary Medical Association, 181, 1066-1068.

5. Beg AA. 2002. Endogenous ligands of Toll-like receptors: implications for regulating inflammatory and immune responses. Trends in Immunology, 23, 509-512.

6. Bischoff SC, Krämer S. 2007. Human mast cells, bacteria, and intestinal immunity. Immunological Reviews, 217, 329-337.

7. Cook DN, Pisetsky DS, Schwartz DA. 2004. Toll-like receptors in the pathogenesis of human disease. Nature Immunology, 5, 975-979.

8. Déry O, Corvera CU, Steinhoff M, Bunnett NW. 1998. Proteinase-activated receptors: novel mechanisms of signaling by serine proteases. American Journal of Physiology, 274, C1429-C1452.
9. Dey I, Chadee K. 2008. Prostaglandin E2 produced by Entamoeba histolytica binds to EP4 receptors and stimulates interleukin-8 production in human colonic cells. Infection and Immunity, 76, 5158-5163.

10. Diamond LS, Harlow DR, Cunnick CC. 1978. A new medium for the axenic cultivation of Entamoeba histolytica and other Entamoeba. Transactions of the Royal Society of Tropical Medicine and Hygiene, 72, 431-432.

11. Espinosa-Cantellano M, Martínez-Palomo A. 2000. Pathogenesis of intestinal amebiasis: from molecules to disease. Clinical Microbiology Reviews, 13, 318-331.

12. Galli SJ, Kalesnikoff J, Grimbaldeston MA, Piliponsky AM, Williams CM, Tsai M. 2005. Mast cells as "tunable" effector and immunoregulatory cells: recent advances. Annual Review of Immunology, 23, 749-786.

13. Ghosh PK, Ventura GJ, Gupta S, Serrano J, Tsutsumi V, Ortiz-Ortiz L. 2000. Experimental amebiasis: immunohistochemical study of immune cell populations. Journal of Eukaryotic Microbiology, 47, 395-399.

14. Hart PH. 2001. Regulation of the inflammatory response in asthma by mast cell products. Immunology and Cell Biology, 79, 149-153.

15. Hou Y, Mortimer L, Chadee K. 2010. Entamoeba histolytica cysteine proteinase 5 binds integrin on colonic cells and stimulates NFkappaB-mediated pro-inflammatory responses. Journal of Biological Chemistry, 285, 35497-35504.

16. Im KI, Hwang HK, Soh CT. 1975. Behaviour of mast cells in Mice in the course of Entamoeba histolytica infection by strains. Korean Journal of Parasitology, 13, 115-122.

17. Iwasaki A, Medzhitov R. 2004. Toll-like receptor control of the adaptive immune responses. Nature Immunology, 5, 987-995.

18. Laughlin RC, McGugan GC, Powell RR, Welter BH, Temesvari LA. 2004. Involvement of raft-like plasma membrane domains of Entamoeba histolytica in pinocytosis and adhesion. Infection and Immunity, 72, 5349-5357.

19. Leippe M, Ebel S, Schoenberger OL, Horstmann RD, MüllerEberhard HJ. 1991. Pore-forming peptide of pathogenic Entamoeba histolytica. Proceedings of the National Academy of Sciences of the United States of America, 88, 7659-7663.

20. McCoy JJ, Mann BJ, Petri WA Jr. 1994. Adherence and cytotoxicity of Entamoeba histolytica or how lectins let parasites stick around. Infection and Immunity, 62, 3045-3050.

21. Mitra BN, Saito-Nakano Y, Nakada-Tsukui K, Sato D, Nozaki T. 2007. Rab11B small GTPase regulates secretion of cysteine proteases in the enteric protozoan parasite Entamoeba histolytica. Cellular Microbiology, 9, 2112-2125.

22. Nozaki T, Asai T, Sanchez LB, Kobayashi S, Nakazawa M, Takeuchi T. 1999. Characterization of the gene encoding serine acetyltransferase, a regulated enzyme of cysteine biosynthesis from the protist parasites Entamoeba histolytica and Entamoeba dispar. Regulation and possible function of the cysteine biosynthetic pathway in Entamoeba. Journal of Biological Chemistry, 274, 32445-32452.

23. Saito-Nakano Y, Mitra BN, Nakada-Tsukui K, Sato D, Nozaki T. 2007. Two Rab7 isotypes, EhRab7A and EhRab7B, play distinct roles in biogenesis of lysosomes and phagosomes in the enteric protozoan parasite Entamoeba histolytica. Cellular Microbiology, 9, 1796-1808.

24. Schäfer T, Starkl P, Allard C, Wolf RM, Schweighoffer T. 2010. A granular variant of CD63 is a regulator of repeated human mast cell degranulation. Allergy, 65, 1242-1255. 
25. Schaudinn F. 1903. Untersuchungen ueber die Fortpflanzung einiger Rhizopoden. Arbeiten aus dem Kaiserlichen Gesundheitsamte, 19, 547-576.

26. Seydel KB, Stanley SL Jr. 1998. Entamoeba histolytica induces host cell death in amebic liver abscess by a non-Fas-dependent, non-tumor necrosis factor $\alpha$-dependent pathway of apoptosis. Infection and Immunity, 66, 2980-2983.
27. Trejo J. 2003. Protease-activated receptors: new concepts in regulation of $\mathrm{G}$ protein-coupled receptor signaling and trafficking. Journal of Pharmacology and Experimental Therapeutics, 307, 437-442.

28. Wedemeyer J, Tsai M, Galli SJ. 2000. Roles of mast cells and basophils in innate and acquired immunity. Current Opinion in Immunology, 12, 624-631.

Cite this article as: Lee YA, Nam YH, Min A, Kim KA, Nozaki T, Saito-Nakano Y, Mirelman D \& Shin MH: Entamoeba histolytica-secreted cysteine proteases induce IL-8 production in human mast cells via a PAR2-independent mechanism. Parasite, 2014, 21, 1 .

\section{(6) PARASTE}

An international open-access, peer-reviewed, online journal publishing high quality papers on all aspects of human and animal parasitology

Reviews, articles and short notes may be submitted. Fields include, but are not limited to: general, medical and veterinary parasitology; morphology, including ultrastructure; parasite systematics, including entomology, acarology, helminthology and protistology, and molecular analyses; molecular biology and biochemistry; immunology of parasitic diseases; host-parasite relationships; ecology and life history of parasites; epidemiology; therapeutics; new diagnostic tools.

All papers in Parasite are published in English. Manuscripts should have a broad interest and must not have been published or submitted elsewhere. No limit is imposed on the length of manuscripts.

Parasite (open-access) continues Parasite (print and online editions, 1994-2012) and Annales de Parasitologie Humaine et Comparée (1923-1993) and is the official journal of the Société Française de Parasitologie. 